\title{
Moult pattern of primaries and secondaries in Eagle Owls Bubo bubo
}

\section{Roar Solheim}

Agder Natural History Museum and Botanical Gardens, P.O. Box 1887 Gimlemoen, N-4686 Kristiansand, Norway. E-mail: roar.solheim@kristiansand.kommune.no

\begin{abstract}
Moult of primaries and secondaries of Scandinavian Eagle Owls Bubo bubo was studied from 42 museum specimens of which the birds'age was known. During their second year they moult the three innermost secondaries (S 13-15). The following summer the moult of secondaries progresses outwards. Primary P7 is moulted, and in many birds also P6 and P8. During their third moult in their fourth summer, Eagle Owls may moult the last secondaries, but still retain 2-3 (4) of the innermost primaries. Even after the fourth moult in their fifth summer, some Eagle Owls may still have some, or at least one, juvenile flight feather left. However, as some birds may lose all juvenile feathers at this stage, Eagle Owls should not be aged higher than $5 \mathrm{C}+$ in autumn, and $6 \mathrm{C}+$ in spring. Scandinavian Eagle Owls seem to moult their flight feathers at a slower pace than other large owls.
\end{abstract}

Key words: owls, moult, ageing

\section{INTRODUCTION}

While some large birds such as ducks, geese, swans, and cranes moult all flight feathers each year, other large birds including large owls and birds of prey take several years to moult all their flight feathers (Edelstam 1984). Usually they start moulting some primaries and secondaries in their second summer. Next year the moult of flight feathers continues, and the birds shed some of the older feathers. In their third moult or even later, the last juvenile feathers are usually lost in many of the largest species. Smaller owl species may annually moult all their flight feathers, as in Hawk Owl Surnia ulula, or some of them, as in Tengmalm's Owl Aegolius funereus (Cieslak \& Kwiecinski 2009, own data).

In some species juvenile flight feathers are distinctively different from older feathers (Edelstam 1984), while in some others there is hardly any difference at all. When juvenile flight feathers are distinct, a bird may be aged quite accurately as long as such juvenile feathers are still present.

Few works describe the moult of flight feathers in owls. Moult is described for Little Owl Athene noctua, Tawny Owl Strix aluco, Long-eared Owl Asio otus and Short-eared Owl Asio flammeus in Baker (1993). The moult of flight feathers of west palearctic owls is described in Cramp (1985), but for Eagle Owls the description is based on studies of captive birds.

This study was based on skin material in the collections of the Natural History Museum of Stockholm (Naturhistoriska Riksmuseet, abbreviated NRM) during visits to NRM in 2010. The museum holds a large collec- tion of Eagle Owl skins, and a considerable number of these specimens are ringed birds of known age. Although some of these birds were captive-bred, they were released as autumn juveniles, and lived as free ranging wild birds when undergoing their moult stages. Some of these skins have been prepared with one loose, spread wing, giving excellent opportunities for moult studies without risking damage to the skins.

I studied this skin collection to examine the duration of the wing moult in Eagle Owls and to explore to what extent the moult patterns can be used for ageing.

\section{MATERIAL AND METHODS}

I inspected all Eagle Owls of known age which had been skinned with at least one free wing. Each wing was photographed with the skin's catalogue number, to reduce the risk of accidentally mixing the material during later analyses. Eagle Owls have 10 primaries like the other owl species, but unlike most other owls, they have 15-16 secondaries (Cramp 1985). The three tertials were not included in the analyses. The feathers were numbered starting from the carpal joint, in the same manner as described for Ural Owls Strix uralensis by Pietiäinen et al. (1984). The primaries and secondaries of each bird were described as being juvenile (J), or non-juvenile feathers (D). The non-juvenile feathers were darker than juvenile feathers, especially the outer vane (Figure 1A). When non-juvenile feathers were unmistakably of different generations, they were given symbols as D1, D2 etc. (D1 being the oldest non-juvenile feathers). 

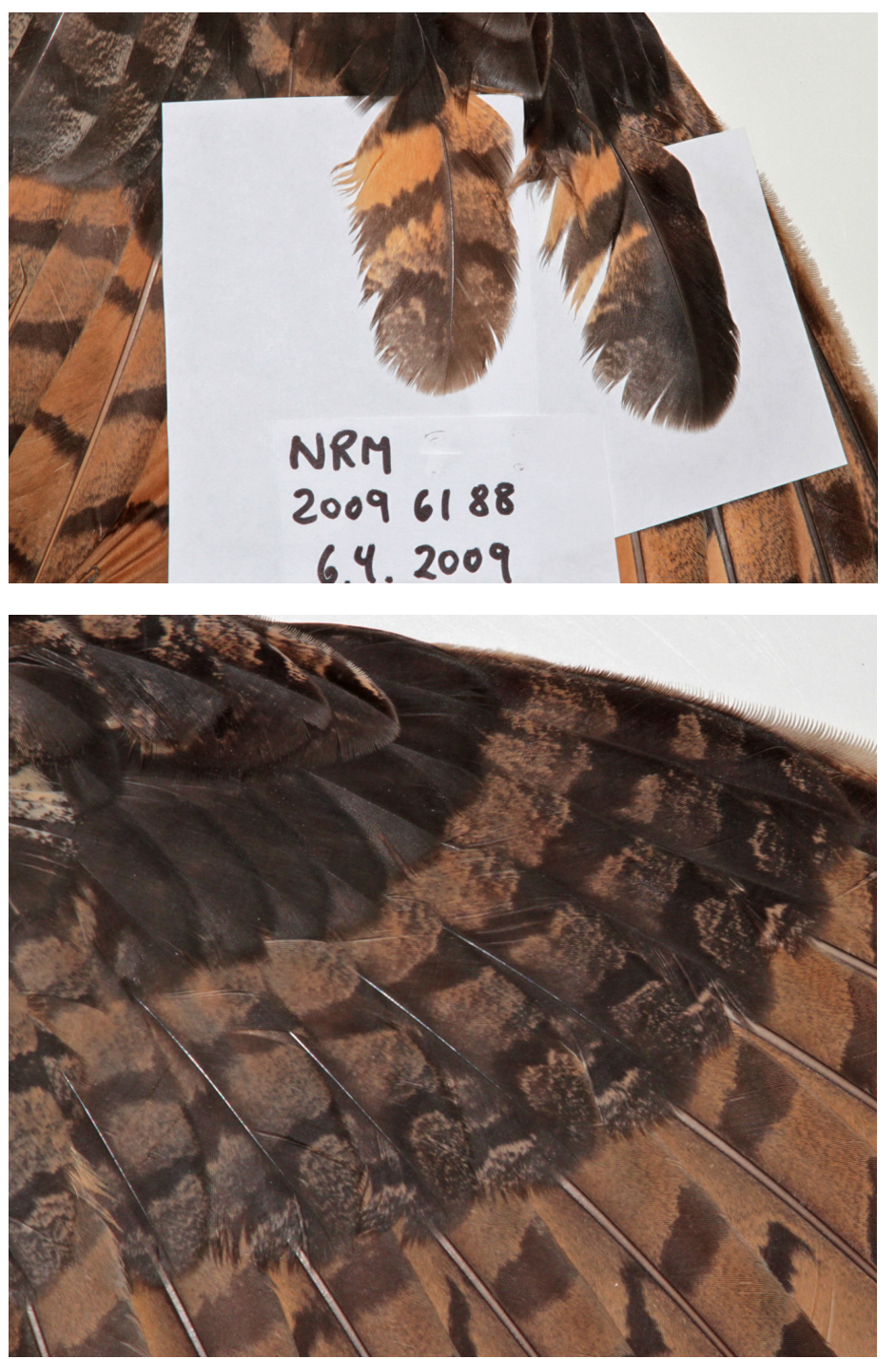

$\mathrm{B}$

Figure 1. A. Juvenile (left) and adult (right) greater coverts of Eagle Owl after second flight feather moult M2 (Catalogue no. 20096188). Dark bands are thinner and more irregular in the juvenile covert. In the adult covert the outer vane is darker and bands are obscured. B. Uniformly juvenile greater coverts of Eagle Owl.

Primary coverts and greater coverts are usually moulted the same summer as the corresponding flight feather is lost. Sometimes contrasts between juvenile and adult feathers are easier to see among coverts than among flight feathers (Figure 1A, B). It is thus of great importance to check the main coverts when inspecting an Eagle Owl wing for moult patterns.

I have used the ageing categories for birds proposed by Runde (1991). A bird is said to be in its first calendar year (1C) from the time of hatching until 31 December. In the following year it is $2 \mathrm{C}$, and so on. A bird of unknown age, but at least in its $\mathrm{X}$ calendar year, is termed $\mathrm{XC}+$. I have added the suffixes "a" (autumn) for birds found in July-December, and "s" (spring) for birds found in January-June. During summer of their second year of life (2C), Eagle Owls moult their first flight feathers, and this moult is termed M1. Next year they enter M2, and so forth.
To determine whether a feather was in active moult, I had to use my fingers and feel for growth sheaths, or I gently lifted underwing coverts with a tweezer to see the status of the feathers. It can be difficult to judge whether a specific secondary is actually missing, because the position of the feathers may be distorted during preparing and drying of the wing. As all checked non-moulting Eagle Owls in the collection had 15 secondaries, I used this number to judge if a gap between secondaries could actually be a missing, moulted feather. Usually such gaps were adjacent to other feathers in active growth (see Figure 2A, B).

Wings from 32 Eagle Owls of known age were photographed and described. Only birds up to and including M4 $(5 \mathrm{Ca} / 6 \mathrm{Cs})$ were used in the moult analyses, and of these 4 were omitted, mainly because the birds were so dark that it was difficult to detect age categories of feathers, leaving 28 birds for the moult study. Also one 


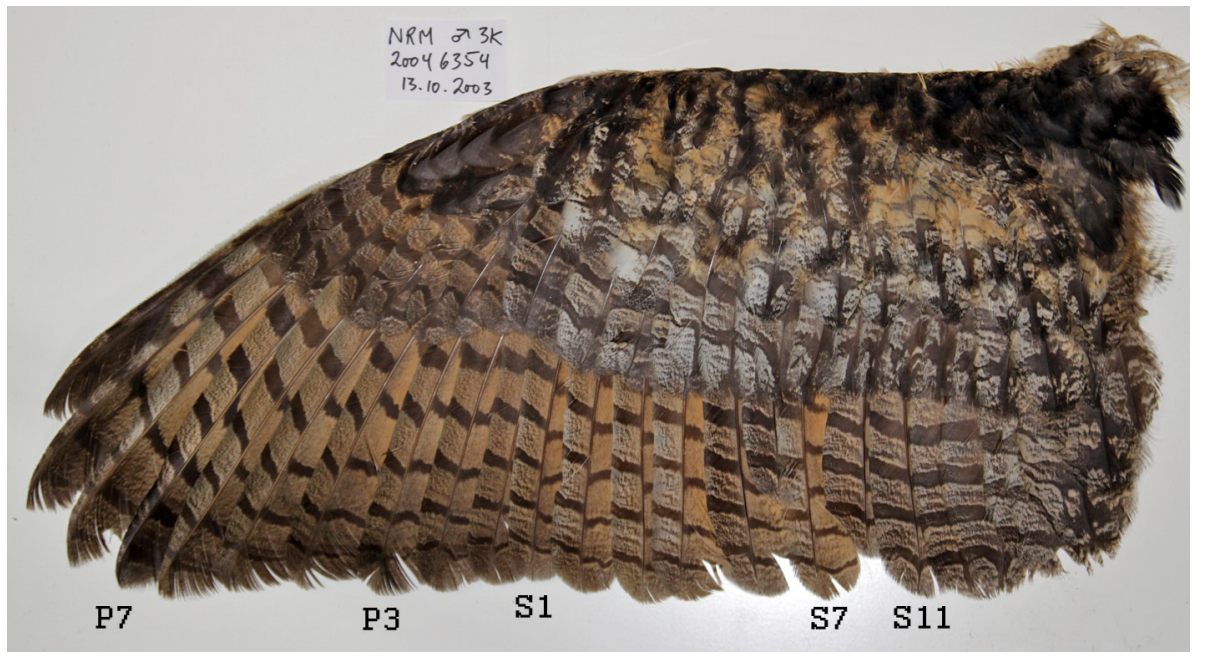

A

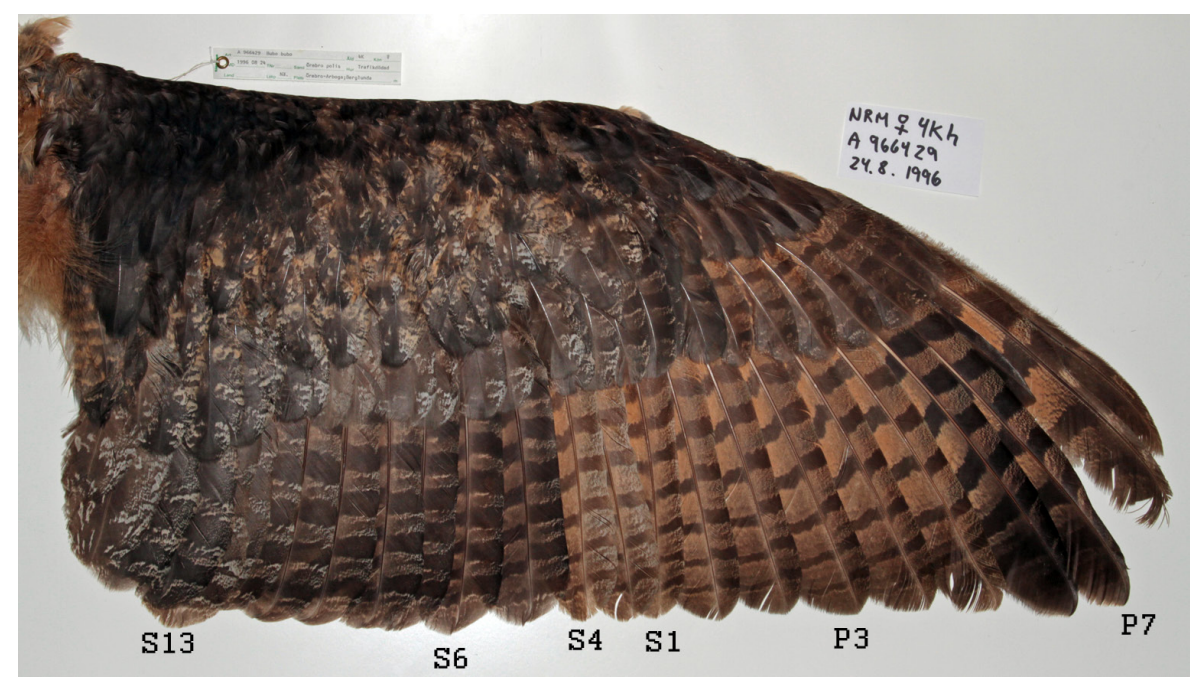

B

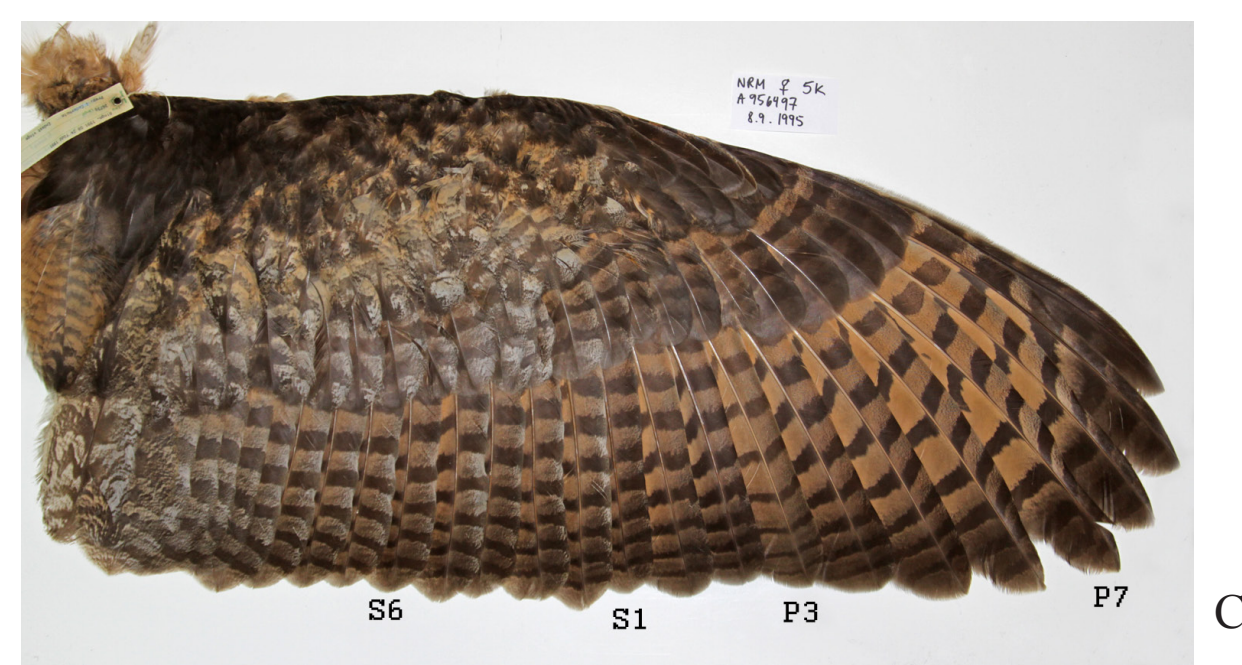

Figure 2. A. Wing of Eagle Owl 20046354 after second flight feather moult M2, showing adult primary P7, and growing secondaries S5, S6 and S10. S8 and S9 seem to be missing, but are hidden beneath the secondary coverts. B. Wing of Eagle Owl 966429 after third flight feather moult M3. Primaries P6-8 have been moulted, and P8 is growing. The other primaries are still juvenile. Secondaries S1, S3 and S4 are juvenile, while S2 has just started growing and is hidden beneath secondary coverts. C. Wing of Eagle Owl 956497 after fourth flight feather moult M4. Primary P3 and adjacent greater covert are still juvenile. At least two generations of secondaries can be recognised. 
Table 1. Number of Eagle Owls in five wing moult categories and with feathers in active growth, according to month. Moult categories: M1 (first moult, birds in their second calendar year), M2 (second moult, birds in their third calendar year), M3 (third moult, birds in their fourth calendar year), M4 (fourth moult, birds in their fifth calendar year) and Older (birds in their sixth calendar year or older). *: One individual not included in moult analyzes. **: Older birds not included in moult pattern analyzes.

\begin{tabular}{|c|c|c|c|c|c|c|c|c|}
\hline \multirow[t]{2}{*}{ Month } & \multicolumn{5}{|c|}{ Moult category } & \multirow[b]{2}{*}{ Sum } & \multirow{2}{*}{$\begin{array}{l}\text { Ind. with } \\
\text { feathers in } \\
\text { growth }\end{array}$} & \multirow{2}{*}{$\begin{array}{l}\text { Mean no of } \\
\text { flight feathers } \\
\text { in moult }\end{array}$} \\
\hline & M1 & M2 & M3 & M4 & Older & & & \\
\hline January & & & $2 *$ & & & 2 & 0 & \\
\hline February & & 3 & $1^{*}$ & & & 4 & 0 & \\
\hline March & & & 2 & & & 2 & 0 & \\
\hline April & & 2 & 1 & & & 3 & 0 & \\
\hline May & & 1 & $2^{*}$ & & & 3 & 0 & \\
\hline June & & $1^{*}$ & & & 2 & 3 & 3 & 4.7 \\
\hline July & & 1 & & 1 & 2 & 4 & 4 & 2.8 \\
\hline August & & & 1 & & 3 & 4 & 4 & 4.7 \\
\hline September & 3 & 3 & $2 *$ & 2 & 2 & 12 & 8 & 3.0 \\
\hline October & & 1 & 1 & & 1 & 3 & 1 & 5.0 \\
\hline November & & & 2 & & & 2 & & \\
\hline December & & & & & & & & \\
\hline Sum & 3 & 12 & 14 & 3 & $10^{* *}$ & & & \\
\hline
\end{tabular}

of these 28 was omitted because it was in mid-moult and could theoretically still have moulted more feathers. 10 older birds had no recognizable juvenile feathers left. Although a pattern of old and fresh feathers may be seen in these birds, such patterns can hardly be used for ageing. These older birds were thus not included in this study, other than defining months with active moult (growing or missing feathers).

\section{RESULTS}

\section{Time of moult}

Individual moult details are given in Appendix 1, where the specimens are referred to by museum catalogue numbers. Twenty birds were in active moult, with feathers either missing or growing (Table 1). These birds were from June-October, with the latest date for a moulting specimen 13 October (Catalogue no. 20046354). Mean number of flight feathers in moult was 4.7 in June, 2.8 in July, 4.7 in August, 3 in September and 5 in October. Of 11 birds in moult category M2 (see below), 5 had flight feathers in active moult, with a mean of 3.8 feathers in moult. Of the 10 birds in the next category M3, only one had flight feathers (2) in active moult. The highest number of birds with feathers in active moult was found in September $(n=8)$.

\section{First moult M1}

Three individuals were classified as belonging to the M1 category, with one $2 \mathrm{Ca}$ bird and two $3 \mathrm{Cs}$ birds. Prima- ries $\mathrm{P} 7$ and $\mathrm{P} 8$ had been cut off on one of the birds, but there were no indications that these had been moulted prior to removal. All primary coverts of these birds were also juvenile (see Figure 1B). None of these birds had moulted any primaries, but all three had moulted the three innermost secondaries S13-15. The moult pattern of these birds is thus easily recognized ( Figure 3A).

\section{Second moult M2}

Eleven individuals were classified to this category. For one of these (Jno. 876582) both wings had been prepared outspread, and included in Appendix 1 because their moult patterns are not completely identical. Five individuals were $3 \mathrm{Ca}$ birds, and six were $4 \mathrm{Cs}$ birds.

All birds moulted primary P7 during their third summer, and a majority also moulted primaries P6 and P8 (Figure 3B). No birds moulted primaries P2-4, and with the exception of one bird where P10 was difficult to categorize, all birds also retained their juvenile P10. A majority also retained the juvenile P9.

The moult of secondaries advanced from the innermost part of the wing, with all birds having moulted S11 and S12. S2 and S5 were moulted in almost all birds. Five birds had moulted S3, and seven had moulted S6. S4 was moulted in only 2 birds, while S7 was moulted in 4 individuals (Figure 3B). All birds had at least one juvenile secondary left (Appendix 1), and two birds had eight juvenile secondaries left in the wing after M2.

\section{Third moult M3}

Of the 11 individuals in the M3 category, one (Catalogue 

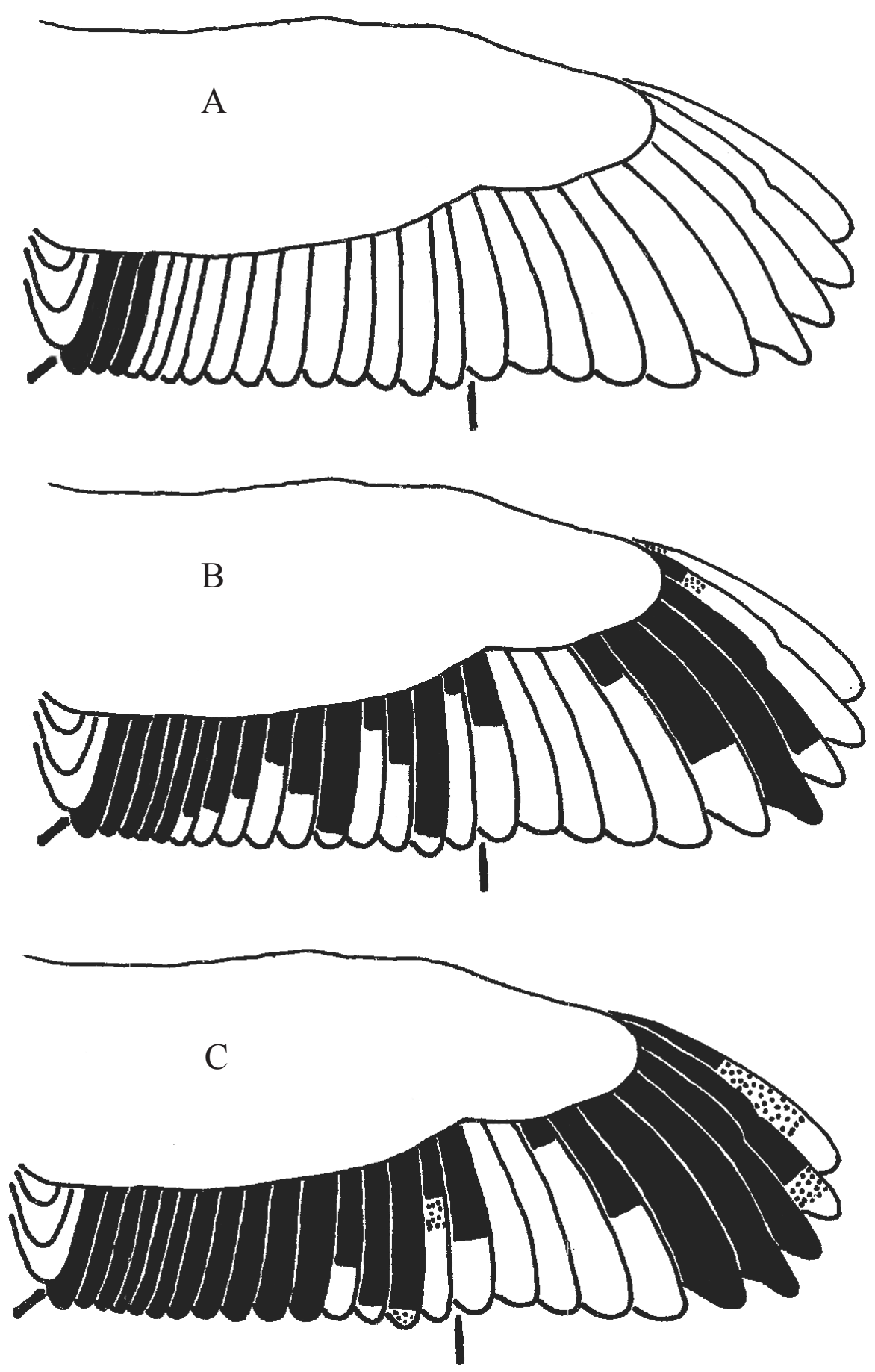

Figure 3. Patterns of adult (black) and juvenile (white) feathers after first (A), second (B) and third (C) flight feather moult of Eagle Owls, based on museum skins from wild birds. The amount of black for each feather indicates the proportion of individuals that had this feather moulted at this stage, the amount of white indicates the proportion of individuals with juvenile feathers and mottled areas indicate the proportion of feathers of uncertain category (see Appendix 1 for exact numbers). Tertials are not included in analyses. 
no. 20046213) was found on 6 June in active moult. It was left out from the analyses of M3 birds, because the bird could still have moulted more feathers had it lived through the summer. Five individuals were 4Ca birds, and five were $5 \mathrm{Cs}$ birds.

The moult of primaries advanced during M3 to include P6-8 in all birds, and P1, 4 and 9 in six, one and eight birds respectively (Appendix 1). All birds did however still retain primaries P2-3 as juveniles, and only one had moulted P4. With the exception of the latter individual, all birds still had at least three juvenile primaries in the wing, with 7 as the maximum number (Catalogue no 966429).

All 10 birds had moulted secondaries S5-15 after their third moult (Figure 3C). Five birds still showed a juvenile $\mathrm{S} 1$. For three more individuals the secondaries were hard to categorize, leaving a possibility that even these had some juvenile secondaries left. Thus only 2 out of 10 birds had with certainty moulted all their secondaries after M3.

\section{Fourth moult M4}

Three birds were classified as M4. In two of them the secondaries were too difficult to classify, but one of these seemed to have one juvenile greater covert left. One had still P3 left as juvenile (Figure 2C), while the third bird had some secondaries which may have been juvenile. In this bird, at least three generations of secondaries were recognized.

\section{Older birds}

No older birds had any juvenile feathers left. 10 birds of age $6 \mathrm{Ca}$ to $19 \mathrm{Ca}$ were checked for number of feathers in growth. Although birds older than $6 \mathrm{Ca}$ may display distinctive patterns of old and new feathers, the moult patterns of these individuals can not be used for ageing.

\section{DISCUSSION}

Through the year, feathers are bleached by sunlight and worn by use. When flight feathers are moulted partially each year, feathers of uneven age will often look different as regards colour, contrast, wear and tear. A pattern of dark and light feathers thus appears. However, the differences between feathers are not always easily observed, unless the bird's wings are examined in good light conditions (daylight or appropriate artificial light).

The Eagle Owls in the NRM collection show marked variation in coloration, from light to very dark individuals. While the wings of the lightest birds appear as bright orange, wings of dark birds are almost blackish-brown. Especially in some dark birds it was difficult, and even impossible, to detect colour differences between flight feathers, although the feathers must obviously be from different moult groups in wings of birds older than $2 \mathrm{Ca}$.

Only one bird in this study was represented with two outstretched wings, and this individual showed slightly asymmetrical moult patterns. The asymmetry was however due to one unmoulted feather only. In similar moult studies on Great Grey Owls (Solheim 2011) and Snowy Owls (Solheim in prep.), such asymmetries are smaller within each moult stage than the overall differences between moult stages. The moult pattern of one wing alone should thus be sufficient to accurately age Scandinavian Eagle Owls up to the age of 6Cs.

Flight feather moult of Eagle Owls advances more slowly than for most of the other owls (Cramp 1985). In the Swedish material, Eagle Owls still had some juvenile feathers left when they were in age category $5 \mathrm{C} / 6 \mathrm{C}$. They may thus first lose all juvenile flight feathers after their fifth moult (M5), as stated in Cramp (1985). No primaries were moulted during M1, as also described (for captive birds) in Cramp (1985), and in Niiranen \& Haapala (1987). Blasco-Zumeta (2010) states that all juvenile flight feathers are lost after M3, and consequently that birds in autumn can only be aged with certainty up to $3 \mathrm{C}$, while older birds should be classified as $4 \mathrm{C}+$. According to Blasco-Zumeta (2010), the Spanish birds also started moulting of primaries P7 and P6 during M1, in their second calendar year. It thus seems that Eagle Owls in southern Europe may start their flight feather moult at an earlier stage than birds of northern Europe, and also that the southern birds complete their first moult cycle faster than northern birds.

According to Cramp (1985) captive Eagle Owls shed their flight feathers from June-August, and no feathers are lost after August. Growth of a flight feather takes 56-84 days, and by the end of October there are no growing feathers left in the wing. This statement for captive birds seems to be confirmed by the present study of wild Eagle Owls.

Moulting flight feathers is an energy demanding process, and the extent of feathers moulted may influence breeding success in later years (Pietiäinen et al. 1984). The slow advance of flight feather moult in Swedish Eagle Owls compared to other large owls like the Great Grey Owl (Solheim 2010, 2011), may reflect the fact that Eagle Owls in Scandinavia are at their most northerly distribution in Europe. Long winters with few prey animals add to the difficulties of Eagle Owls' survival. The quicker advance of flight feather moulting which seems to take place in Eagle Owls of southern Europe (Blasco-Zumeta 2010), could be caused by genetic differences, but are more likely explained by differences in prey availability.

I have not separated sexes in this moult study, as the differences in moult pattern from one year to the next seem to be greater than the individual variation within each moult stage. However, as moult puts a load on the energy budget of the birds, a closer analysis of moult patterns of males versus females may reveal sex differences, and in addition breeding versus non-breeding birds should be expected to show differences in the amount 
of moulted flight feathers. Such analyses can only be done on live birds where breeding status is known, and is most practically done on nest-box breeding owls as shown for the Ural Owl (Pietiäinen et al. 1984). The higher number of flight feathers lost in M2 than in M3, may reflect birds not attempting to breed before they reach their fourth calendar year.

The results from this study are exclusively based on free living Eagle Owls from Sweden. In Scandinavia, Eagle Owls seem to have the best prey availability and population density along the outer coast of Nordland, northern Norway. Unfortunately there is no material available to check the progress of flight feather moulting of birds from these areas. It thus remains to be seen whether Eagle Owls of Norwegian coastal habitats may follow a moulting pattern similar to birds from southern Europe, or progress at the same speed as the Swedish birds. Dead Eagle Owls from coastal Norway are thus of great value for closer studies on moult patterns of this species.

Acknowledgements. I thank Naturhistoriska Riksmuseet in Stockholm for permission to study their collections of owl wings, and Göran Frisk and Thord Fransson in particular for finding material and providing data sheets of the skins. Vidar Selås and Jan Ove Gjershaug gave valuable comments and suggestions to improve the manuscript, of which I am grateful. I also thank Pertti Saurola and Morten Helberg for bringing other moult studies to my attention. I am grateful to the Norwegian Directorate for nature management, which supported this study, covering travel costs.

Sammendrag. Mytemønster i håndsving- og armsvingfjær hos hubro. Myting av vingefjær ble studert hos 42 hubroskinn med kjent alder. I sitt andre leveår starter hubroene med å myte de tre innerste armsvingfjærene (S13-15). Neste sommer fortsetter armsvingfjærmytingen utover fra disse, samtidig med at håndsvingfjær P7 mytes. Mange fugler skifter også håndsvingfjær P6 og P8 dette året. I sin tredje vingefjærmyting (fjerde kalenderår) kan hubroene felle de siste armsvingfjærene, men de beholder som regel de innerste 2-3 (4) håndsvingfjærene som juvenile. Til og med etter sin fjerde vingefjærmyting i femte kalenderår kan noen hubroer ha noen, eller i det minste en, juvenil vingefjær tilbake. Siden noen hubroer likevel kan ha skiftet alle juvenile vingefjær ved fjerde svingfjærmyting, bør hubroer ikke aldersbestemmes på grunnlag av mytemønster høyere enn $5 \mathrm{~K}+$ på høsten og $6 \mathrm{~K}+$ om våren. Skandinaviske hubroer ser ut til å skifte vingefjær i langsommere tempo enn andre store ugler.

\section{REFERENCES}

Baker, K. 1993. Identification guide to European non-Passerines. BTO guide 24. British Trust for Ornithology, Thetford.

Blasco-Zumeta, J. 2010. Identification atlas of birds of Aragon. http://www.ibercajalav.net (accessed Sept. 2010.)

Cieslak, M. \& Kwieschinski, Z. 2009. Moult and breeding of captive Northern Hawk Owls Surnia ulula. Ardea 97: 571-579.

Cramp, S. (ed) 1985. Handbook of the birds of Europe, the Middle East and North Africa, Vol. IV. Terns to woodpeckers. Oxford Univ. Press, Oxford.

Edelstam, C. 1984: Patterns of moult in large birds of prey. Ann. Zool. Fennici 21: 271-276.

Niiranen, S. \& Haapala, J. 1987. Huukajan iän määrittäminen. Lintumies 22: 112-116.

Pietiäinen, H., Saurola, P. \& Kolunen, H.1984. The reproductive constraints on moult in the Ural Owl Strix uralensis. Ann. Zool. Fennici 21: 277-281.

Runde, O.J. 1991. Ringmerkerens håndbok. Stavanger Museum, Stavanger.

Solheim, R. 2010. Kan lappugglor individbestämmas utan infångande och märkning? Vår Fågelvärld 69: 8-12.

Solheim, R. 2011. Molt pattern of primaries and secondaries during first and second flight feather molt in Great Grey Owls Strix nebulosa. Ornis Svecica 21: 11-19.

Received 1 February 2011. Accepted 6 April 2011 
Appendix 1. Eagle Owl flight feather moult patterns from skins at the Natural History Museum, Stockholm. C: calendar year; s: spring; a: autumn; J: juvenile feather; D: adult (dark) feather; D1: first generation adult feather; D2. second generation adult feather; D3: third generation adult feather; small letter: feather in growth.

Catalogue

number

Age

Primaries

$\begin{array}{lllllllllll}10 & 9 & 8 & 7 & 6 & 5 & 4 & 3 & 2 & 1\end{array}$

Moult category $M 1$

$20046012-3 \mathrm{Cs}$

$20036593 \quad 3 \mathrm{Cs}$

Sum juvenile feathers

(1)

Moult category M2

\begin{tabular}{|c|c|c|c|c|c|c|c|c|c|c|}
\hline 876582 & $3 \mathrm{Ca}$ & $\mathrm{J}$ & $\mathrm{J}$ & $\mathrm{D}$ & $\mathrm{D}$ & $\mathrm{D}$ & $\mathrm{D}$ & $\mathrm{J}$ & $\mathrm{J}$ & $\mathrm{J}$ \\
\hline 876582 & $3 \mathrm{Ca}$ & $\mathrm{J}$ & $\mathrm{J}$ & $\mathrm{D}$ & $\mathrm{D}$ & $\mathrm{D}$ & $\mathrm{D}$ & $\mathrm{J}$ & $\mathrm{J}$ & $\mathrm{J}$ \\
\hline 886310 & $3 \mathrm{Ca}$ & $\mathrm{J}$ & $\mathrm{J}$ & $\mathrm{d}$ & $\mathrm{D}$ & $\mathrm{D}$ & $\mathrm{J}$ & $\mathrm{J}$ & $\mathrm{J}$ & $\mathrm{J}$ \\
\hline 886373 & $4 \mathrm{Cs}$ & $\mathrm{J}$ & $\mathrm{J}$ & $\mathrm{D}$ & $\mathrm{D}$ & $\mathrm{J}$ & $\mathrm{J}$ & $\mathrm{J}$ & $\mathrm{J}$ & $\mathrm{J}$ \\
\hline 956318 & $3 \mathrm{Ca}$ & $\mathrm{J}$ & $\mathrm{J}$ & $\mathrm{J}$ & $\mathrm{d}$ & $\mathrm{d}$ & $\mathrm{J}$ & $\mathrm{J}$ & $\mathrm{J}$ & $\mathrm{J}$ \\
\hline 986501 & $3 \mathrm{Ca}$ & $\mathrm{J}$ & $\mathrm{d}$ & $\mathrm{D}$ & $\mathrm{D}$ & $\mathrm{D}$ & $\mathrm{D}$ & $\mathrm{J}$ & $\mathrm{J}$ & $\mathrm{J}$ \\
\hline 20046047 & $4 \mathrm{Cs}$ & $\mathrm{J}$ & $\mathrm{J}$ & $\mathrm{D}$ & D? & $\mathrm{D}$ & $\mathrm{J}$ & $\mathrm{J}$ & $\mathrm{J}$ & $\mathrm{J}$ \\
\hline 20046354 & $3 \mathrm{Ca}$ & $\mathrm{J}$ & $\mathrm{J}$ & $\mathrm{J}$ & $\mathrm{D}$ & $\mathrm{J}$ & $\mathrm{J}$ & $\mathrm{J}$ & $\mathrm{J}$ & $\mathrm{J}$ \\
\hline 976058 & $4 \mathrm{Cs}$ & D? & D? & $\mathrm{D}$ ? & $\mathrm{D}$ & $\mathrm{D}$ & $\mathrm{J}$ & $\mathrm{J}$ & $\mathrm{J}$ & $\mathrm{J}$ \\
\hline 986055 & $4 \mathrm{Cs}$ & $\mathrm{J}$ & $\mathrm{J}$ & $\mathrm{D}$ & $\mathrm{D}$ & $\mathrm{J}$ & $\mathrm{J}$ & $\mathrm{J}$ & $\mathrm{J}$ & $\mathrm{J}$ \\
\hline 20056134 & $4 \mathrm{Cs}$ & $\mathrm{J}$ & $\mathrm{J}$ & $\mathrm{D}$ & $\mathrm{D}$ & $\mathrm{J}$ & $\mathrm{J}$ & $\mathrm{J}$ & $\mathrm{J}$ & $\mathrm{J}$ \\
\hline 20096188 & $4 \mathrm{Cs}$ & $\mathrm{J}$ & $\mathrm{J}$ & $\mathrm{D}$ & $\mathrm{D}$ & $\mathrm{D}$ & $\mathrm{J}$ & $\mathrm{J}$ & $\mathrm{J}$ & $\mathrm{J}$ \\
\hline Sum juven & feathers & 9 & 9 & 2 & 0 & 4 & 9 & 11 & 11 & 11 \\
\hline
\end{tabular}

Moult category M3

20046213 4Cs

$896154 \quad 5 \mathrm{Cs}$

J J

D D

D

d

896174

J D

D

D

D

$\mathrm{J}$

D D2

$926083 \quad 5 \mathrm{Cs}$

D D

D2

D1

D2

D1

966429

$4 \mathrm{Ca}$

966679

$4 \mathrm{Ca}$

J J

d2

D1

D2

986521

$4 \mathrm{Ca}$

D

D

D

986629

$4 \mathrm{Ca}$

$\mathrm{D} / \mathrm{J} \quad \mathrm{D} 2$

D1

D1

D

$20056513 \quad 4 \mathrm{Ca}$

D2 D2

D2

D1

D1

D1

D

D

$20096044 \quad 5 \mathrm{Cs}$

$\begin{array}{ll}\mathrm{D} & \mathrm{D} \\ \mathrm{J} & \mathrm{J} ?\end{array}$

D2

D1

D2

20096157

$5 \mathrm{Cs}$

$\mathrm{D} / \mathrm{J} \quad \mathrm{D} 2$

D2

D1

D1

Sum juvenile feathers

00

0

D2

D2

J J

$\begin{array}{lllll}\mathrm{J} & \mathrm{J} & \mathrm{J} & \mathrm{J} & \mathrm{J}\end{array}$

$\begin{array}{lllll}\mathrm{D} 2 & \mathrm{~J} & \mathrm{~J} & \mathrm{~J} & \mathrm{D}\end{array}$

Moult category M4

$\begin{array}{llllllllllll}587243 & 5 \mathrm{Ca} & \mathrm{D} & \mathrm{D} & \mathrm{D} & \mathrm{D} & \mathrm{D} & \mathrm{D} 1 & \mathrm{D} 3 & \mathrm{D} 3 & \mathrm{D} 3 & \mathrm{D} \\ 926247 & 5 \mathrm{Ca} & - & \mathrm{D} & \mathrm{D} & \mathrm{D} & \mathrm{D} 1 & \mathrm{D} & \mathrm{d} 3 & \mathrm{~d} 3 & \mathrm{D} & \mathrm{D} \\ 956497 & 5 \mathrm{Ca} & \mathrm{D} & \mathrm{D} & \mathrm{D} & \mathrm{D} & \mathrm{D} 1 & \mathrm{D} 2 & \mathrm{D} 2 & \mathrm{~J} & \mathrm{D} 2 & \mathrm{D} \\ \text { Sum juvenile feathers } & 0 & 0 & 0 & 0 & 0 & 0 & 1 & 0 & 0 & 0\end{array}$

1) Primaries No. 7 and 8 had been cut off. 2) Right wing. 3) Left wing. 4) Had started third moult, excluded from analyses. 5) Secondaries difficult to categorize, at least two adult generations. 6) Inseparable adult generations. 7) No clear juvenile feathers, at least two adult generations. 8) Three adult generations of secondaries. 9) No clear juvenile feathers, at least two adult generations; greater covert number 4 appears juvenile. 10) No juvenile generations, at least two adult generations. 


\begin{tabular}{|c|c|c|c|c|c|c|c|c|c|c|c|c|c|c|c|}
\hline 1 & 2 & 3 & 4 & 5 & 6 & 7 & 8 & 9 & 10 & 11 & 12 & 13 & 14 & 15 & \\
\hline $\mathrm{J}$ & $\mathrm{J}$ & $\mathrm{J}$ & $\mathrm{J}$ & $\mathrm{J}$ & $\mathrm{J}$ & $\mathrm{J}$ & $\mathrm{J}$ & $\mathrm{J}$ & $\mathrm{J}$ & $\mathrm{J}$ & $\mathrm{J}$ & $\mathrm{D}$ & $\mathrm{D}$ & $\mathrm{D}$ & \\
\hline $\mathrm{J}$ & $\mathrm{J}$ & $\mathrm{J}$ & $\mathrm{J}$ & $\mathrm{J}$ & $\mathrm{J}$ & $\mathrm{J}$ & $\mathrm{J}$ & $\mathrm{J}$ & $\mathrm{J}$ & $\mathrm{J}$ & $\mathrm{J}$ & $\mathrm{D}$ & $\mathrm{D}$ & $\mathrm{D}$ & 1) \\
\hline $\mathrm{J}$ & $\mathrm{J}$ & $\mathrm{J}$ & $\mathrm{J}$ & $\mathrm{J}$ & $\mathrm{J}$ & $\mathrm{J}$ & $\mathrm{J}$ & $\mathrm{J}$ & $\mathrm{J}$ & $\mathrm{J}$ & $\mathrm{J}$ & $\mathrm{D}$ & $\mathrm{D}$ & $\mathrm{D}$ & \\
\hline 3 & 3 & 3 & 3 & 3 & 3 & 3 & 3 & 3 & 3 & 3 & 3 & 0 & 0 & 0 & \\
\hline $\mathrm{d}$ & D & $\mathrm{d}$ & $\mathrm{J}$ & D & $\mathrm{D}$ & $\mathrm{d}$ & $\mathrm{d}$ & $\mathrm{D}$ & $\mathrm{D}$ & $\mathrm{D}$ & $\mathrm{D}$ & $\mathrm{D}$ & $\mathrm{d}$ & $\mathrm{D}$ & 2) \\
\hline $\mathrm{J}$ & $\mathrm{d}$ & $\mathrm{d}$ & $\mathrm{J}$ & $\mathrm{D}$ & $\mathrm{d}$ & $\mathrm{d}$ & $\mathrm{d}$ & $\mathrm{D}$ & $\mathrm{D}$ & $\mathrm{D}$ & $\mathrm{D}$ & $\mathrm{D}$ & $\mathrm{D}$ & $\mathrm{D}$ & 3) \\
\hline $\mathrm{J}$ & $\mathrm{d}$ & $\mathrm{J}$ & $\mathrm{J}$ & D & $\mathrm{J}$ & $\mathrm{J}$ & $\mathrm{J}$ & $\mathrm{J}$ & $\mathrm{D}$ & $\mathrm{D}$ & $\mathrm{D}$ & $\mathrm{D}$ & $\mathrm{D}$ & $\mathrm{D}$ & \\
\hline $\mathrm{J}$ & $\mathrm{D}$ & $\mathrm{J}$ & $\mathrm{J}$ & D & $\mathrm{D}$ & $\mathrm{J}$ & $\mathrm{D}$ & $\mathrm{D}$ & $\mathrm{D}$ & $\mathrm{D}$ & $\mathrm{D}$ & $\mathrm{D}$ & $\mathrm{D}$ & $\mathrm{D}$ & \\
\hline $\mathrm{J}$ & $\mathrm{d}$ & $\mathrm{J}$ & $\mathrm{J}$ & $\mathrm{d}$ & $\mathrm{J}$ & $\mathrm{J}$ & $\mathrm{J}$ & $\mathrm{J}$ & $\mathrm{J}$ & $\mathrm{d}$ & D & $\mathrm{D}$ & $\mathrm{D}$ & $\mathrm{D}$ & \\
\hline $\mathrm{J}$ & $\mathrm{D}$ & $\mathrm{D}$ & $\mathrm{d}$ & $\mathrm{J}$ & $\mathrm{D}$ & $\mathrm{D}$ & $\mathrm{D}$ & $\mathrm{D}$ & $\mathrm{D}$ & $\mathrm{D}$ & $\mathrm{D}$ & $\mathrm{d}$ & $\mathrm{D}$ & $\mathrm{D}$ & \\
\hline $\mathrm{J}$ & $\mathrm{D}$ & $\mathrm{D}$ & $\mathrm{D}$ & $\mathrm{D}$ & $\mathrm{D}$ & $\mathrm{D}$ & $\mathrm{D}$ & $\mathrm{D}$ & $\mathrm{D}$ & $\mathrm{D}$ & $\mathrm{D}$ & $\mathrm{D}$ & $\mathrm{D}$ & $\mathrm{D}$ & \\
\hline $\mathrm{J}$ & $\mathrm{J}$ & $\mathrm{J}$ & $\mathrm{J}$ & $\mathrm{d}$ & $\mathrm{d}$ & $\mathrm{J}$ & $\mathrm{d}$ & $\mathrm{d}$ & $\mathrm{d}$ & $\mathrm{D}$ & D & $\mathrm{D}$ & $\mathrm{D}$ & $\mathrm{D}$ & \\
\hline $\mathrm{D}$ & D & $\mathrm{D}$ & $\mathrm{J}$ & D & $\mathrm{D}$ & $\mathrm{J}$ & $\mathrm{D}$ & $\mathrm{D}$ & $\mathrm{D}$ & $\mathrm{D}$ & D & $\mathrm{D}$ & $\mathrm{D}$ & $\mathrm{D}$ & \\
\hline $\mathrm{J}$ & $\mathrm{D}$ & $\mathrm{J}$ & $\mathrm{J}$ & $\mathrm{D}$ & $\mathrm{D}$ & $\mathrm{D}$ & $\mathrm{D}$ & $\mathrm{D}$ & $\mathrm{D}$ & $\mathrm{D}$ & $\mathrm{D}$ & $\mathrm{D}$ & $\mathrm{D}$ & $\mathrm{D}$ & \\
\hline $\mathrm{J}$ & D & $\mathrm{J}$ & $\mathrm{J}$ & D & $\mathrm{J}$ & $\mathrm{J}$ & $\mathrm{J}$ & $\mathrm{J}$ & $\mathrm{J}$ & $\mathrm{D}$ & D & $\mathrm{D}$ & $\mathrm{D}$ & $\mathrm{D}$ & \\
\hline $\mathrm{J}$ & D & $\mathrm{D}$ & $\mathrm{J}$ & D & $\mathrm{J}$ & $\mathrm{J}$ & $\mathrm{J}$ & $\mathrm{D}$ & $\mathrm{D}$ & $\mathrm{D}$ & D & $\mathrm{D}$ & $\mathrm{D}$ & $\mathrm{D}$ & \\
\hline 9.5 & 1 & 6 & 9 & 1 & 4 & 7 & 4 & 3 & 2 & 0 & 0 & 0 & 0 & 0 & \\
\hline $\mathrm{J}$ & $\mathrm{D}$ & $\mathrm{D}$ & $\mathrm{D}$ & $\mathrm{D}$ & $\mathrm{D}$ & $\mathrm{D}$ & $\mathrm{D}$ & $\mathrm{D}$ & $\mathrm{D}$ & $\mathrm{D}$ & $\mathrm{D}$ & $\mathrm{D}$ & D2 & D2 & 4) \\
\hline $\mathrm{J}$ & D1 & D1 & D2 & D1 & D2 & D & $\mathrm{D}$ & $\mathrm{D}$ & $\mathrm{D}$ & $\mathrm{D}$ & D1 & D1 & D1 & D2 & \\
\hline $\mathrm{J} ?$ & $\mathrm{D}$ & $\mathrm{D}$ & $\mathrm{D}$ & $\mathrm{D}$ & $\mathrm{D}$ & $\mathrm{D}$ & $\mathrm{D}$ & $\mathrm{D}$ & $\mathrm{D}$ & $\mathrm{D}$ & $\mathrm{D}$ & $\mathrm{D}$ & $\mathrm{D}$ & $\mathrm{D}$ & 5) \\
\hline $\mathrm{J} ?$ & $\mathrm{D}$ & $\mathrm{D}$ & $\mathrm{D}$ & $\mathrm{D}$ & $\mathrm{D}$ & $\mathrm{D}$ & $\mathrm{D}$ & $\mathrm{D}$ & $\mathrm{D}$ & $\mathrm{D}$ & $\mathrm{D}$ & $\mathrm{D}$ & $\mathrm{D}$ & $\mathrm{D}$ & 5) \\
\hline $\mathrm{J}$ & $\mathrm{d} 2$ & $\mathrm{~J}$ & $\mathrm{~J}$ & D2 & D2 & D2 & D2 & D2 & D2 & $\mathrm{D} 2$ & D1 & D1 & D2 & D2 & \\
\hline $\mathrm{D}$ & J? & $\mathrm{D}$ & $\mathrm{D}$ & J? & $\mathrm{D}$ & $\mathrm{D}$ & $\mathrm{D}$ & $\mathrm{D}$ & $\mathrm{D}$ & $\mathrm{D}$ & D & $\mathrm{D}$ & $\mathrm{D}$ & $\mathrm{D}$ & 6) \\
\hline $\mathrm{D}$ & $\mathrm{D}$ & $\mathrm{D}$ & $\mathrm{D}$ & $\mathrm{D}$ & $\mathrm{D}$ & $\mathrm{D}$ & $\mathrm{D}$ & $\mathrm{D}$ & $\mathrm{D}$ & $\mathrm{D}$ & $\mathrm{D}$ & $\mathrm{D}$ & $\mathrm{D}$ & $\mathrm{D}$ & 7) \\
\hline $\mathrm{D}$ & D & $\mathrm{D}$ & $\mathrm{D}$ & D & $\mathrm{D}$ & D & $\mathrm{D}$ & $\mathrm{D}$ & $\mathrm{D}$ & $\mathrm{D}$ & $\mathrm{D}$ & $\mathrm{D}$ & $\mathrm{D}$ & $\mathrm{D}$ & 7) \\
\hline $\mathrm{J}$ & $\mathrm{D}$ & $\mathrm{D}$ & $\mathrm{J}$ & D1 & D1 & D2 & D2 & $\mathrm{D}$ & $\mathrm{D}$ & $\mathrm{D}$ & $\mathrm{D}$ & $\mathrm{D}$ & $\mathrm{D}$ & $\mathrm{D}$ & \\
\hline $\mathrm{J}$ & D2 & D2 & $\mathrm{J}$ & D1 & D1 & D2 & D2 & D2 & D1 & D1 & D1 & D1 & D2 & D2 & \\
\hline $\mathrm{J}$ & D2 & D1 & $\mathrm{D}$ & $\mathrm{D}$ & $\mathrm{D}$ & $\mathrm{D}$ & $\mathrm{D}$ & $\mathrm{D}$ & D2 & $\mathrm{D} 1$ & D1 & D2 & D2 & D1 & \\
\hline 5 & 0 & 1 & 3 & 0 & 0 & 0 & 0 & 0 & 0 & 0 & 0 & 0 & 0 & 0 & \\
\hline D2 & D2 & D3 & $\mathrm{D} / \mathrm{J}$ & D2 & D3 & $\mathrm{D} / \mathrm{J}$ & D3 & D2 & D2 & $\mathrm{D} 2$ & D1 & D2 & D1 & D2 & 8) \\
\hline $\mathrm{D}$ & D & $\mathrm{D}$ & $\mathrm{D}$ & D & $\mathrm{D}$ & $\mathrm{D}$ & $\mathrm{D}$ & D & $\mathrm{D}$ & $\mathrm{D}$ & D & $\mathrm{D}$ & $\mathrm{D}$ & $\mathrm{D}$ & 9) \\
\hline $\mathrm{D}$ & $\mathrm{D}$ & $\mathrm{D}$ & $\mathrm{D}$ & $\mathrm{D}$ & $\mathrm{D}$ & $\mathrm{D}$ & $\mathrm{D}$ & $\mathrm{D}$ & $\mathrm{D}$ & $\mathrm{D}$ & $\mathrm{D}$ & $\mathrm{D}$ & $\mathrm{D}$ & $\mathrm{D}$ & 10) \\
\hline 0 & 0 & 0 & 0 & 0 & 0 & 0 & 0 & 0 & 0 & 0 & 0 & 0 & 0 & 0 & \\
\hline
\end{tabular}

